\title{
Larvicidal potencial of Sapindus saponaria (Sapindaceae) against Rhipicephalus sanguineus (Latreille, 1806) (Acari: Ixodidae).
}

\author{
[Potencial larvicida de Sapindus saponaria (Sapindaceae) sobre Rhipicephalus sanguineus \\ (Latreille, 1806) (Acari: Ixodidae)]

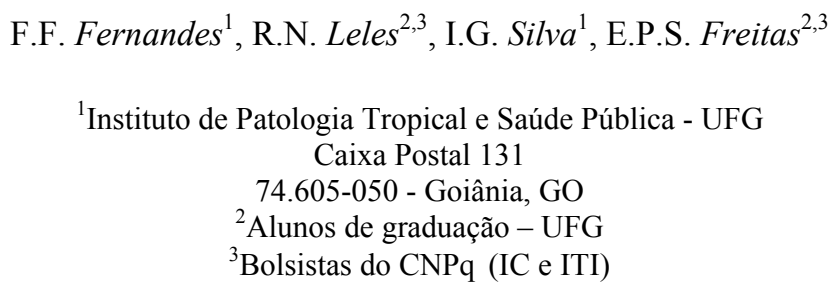

\begin{abstract}
The larvicidal potential of the crude ethanolic extracts (CEE) of the stem peel of Sapindus saponaria was evaluated against Rhipicephalus sanguineus. Lethal concentrations (LC), were calculated by preparing CEE solutions at different concentrations in distilled water. Larvae fasted for 14-21 days were utilized in the bioassays, after incubation of engorged females collected from infested environments frequented by dogs in several neighborhoods of Goiânia, GO. Bioassays were performed in a specially constructed biological chamber for testing botanical acaricides, acclimatized to $27 \pm 1^{\circ} \mathrm{C}, \mathrm{RH}>80 \%$. The larvae were counted on filter paper envelopes impregnated with the solutions or distilled water and larval mortality observed after 48h. S. saponaria showed good larvicidal activity ( LC $_{50}$ and LC $_{99}$ of 1994 and 3922ppm, respectively) and the results demonstrated its potential as a botanical acaricide and an alternative control measure for $R$. sanguineus.
\end{abstract}

Keywords: tick control, Rhipicephalus sanguineus, Sapindus saponaria, soapberry, botanical acaricide

\section{RESUMO}

Avaliou-se a potencialidade larvicida do extrato-bruto etanólico (EBE) da casca do caule de Sapindus saponaria sobre Rhipicephalus sanguineus. Para o cálculo das concentrações letais (CL) foram preparadas soluções com diferentes concentrações do EBE dissolvido em água destilada. Foram utilizadas larvas em jejum com 14 a 21 dias, obtidas pela incubação de teleóginas, coletadas em ambientes infestados, freqüentados por cães de vários bairros de Goiânia. Os bioensaios foram realizados em uma câmara biológica para testes com acaricidas botânicos, climatizada a $27 \pm 1^{\circ} \mathrm{C} e$ $U R>80 \%$. As larvas foram contidas em envelopes de papel filtro impregnados com as soluções (grupo teste) ou com água destilada (grupo-controle) e a mortalidade larval foi observada após $48 \mathrm{~h}$. $\mathrm{S}$. saponaria demonstrou atividade larvicida satisfatória $\left(C L_{50}\right.$ e $C L_{99}$ respectivamente de 1994 e 3922 ppm) e os resultados demonstraram seu potencial como acaricida botânico e medida alternativa para o controle de $\mathrm{R}$. sanguineus.

Palavras-chave: controle de carrapatos, Rhipicephalus sanguineus, Sapindus saponaria, saponácea, acaricida botânico

Recebido em 23 de setembro de 2005

Aceito em 4 de janeiro de 2007

E-mail: E-mail: ffreitas@iptsp.ufg.br

Apoio: CNPq, SETEC-GO, FUNAPE-UFG 


\section{INTRODUCTION}

Rhipicephalus sanguineus is a cosmopolitan three-host tick and one of the most widely distributed members of the Ixodidae. Different strains are involved in the transmission of Ehrlichia canis, Babesia canis, B. caballi, B. gibsoni, Theileria equi, Hepatozoon canis, Haemobartonella canis, Rickettsia conorii, and Rickettsia rickettsii, which cause diseases of the spotted fever etiological group in several parts of the world (Burgdorfer et al., 1975; Sexton et al., 1976; Woldehiwet and Ristic, 1993). Occasional feeding on man has resulted an in increased incidence of some of these diseases as emergent zooanthroponoses (Hoogstraal, 1967; Andereg and Passos, 1999).

Despite of the availability on the market of a diversity of acaricidal products for dogs, this tick is highly prevalent in most Brazilian municipalities. Its presence is aggravated by the increasing development in some strains of resistance to acaricides such as pyrethroids and the inefficacy of other compounds (Fernandes, 2000; Fernandes and Freitas, 2001; Miller et al., 2001). Resistance is believed to be due to the continuous misuse of acaricidal products in dogs, since until recently no products had benn specifically developed for them. Chemicals developed for using in cattle or horses or for environmental disinfestations were applied in diverse doses and forms of application (including injections and topical treatments based on powders or liquids).

This history of incorrect use has probably led to a significant reduction in sensitivity of the target site of these acaricides, i.e., sodium channels of the nervous system, producing Knockdown resistance (Kdr) (Hervé, 1983; Wang et al., 2002). This was first noted among $R$. sanguineus larvae in Goiânia, capital of the Brazilian state of Goiás, by Fernandes (2000) and Fernandes et al. (2001). In this municipality, R. sanguineus may possess two different resistance mechanisms, given its resistance to deltamethrin but not permethrin, both pyrethroids (Fernandes 2000; Fernandes et al., 2001). A similar situation was observed in Panamanian strains of that tick, whose resistance was characterized by increased esterase levels as well as $K d r$ (Miller et al., 2001).
Difficulties in controlling $R$. sanguineus have prompted studies to develop new alternatives. There is a worldwide tendency to reduce chemical insecticide and acaricide use as much as possible, principally due to the damage these compounds cause to the environment and food chain. The use of plants with insecticidal properties constitutes one alternative with lower environmental impact.

The soapberry Sapindus saponaria L. (Sapindaceae) occurs in the USA, Mexico and Argentina as well as the Brazilian states of Amazonas, Goiás, Mato Grosso and Mato Grosso do Sul. This tree is much used in urban landscaping and its wood is utilized in civil construction, as well as to make toys, boxes and souvenirs. Its fruit and seeds have foaming properties due to their saponin content. According to Pott \& Pott (1994) the triturated fruit serves as a soap while the seed is employed for producing oil for soap manufacture and is widely used as an insecticide (Guarin Neto et al., 2000). The CEE of $S$. saponaria also presents promising larvicidal activity against the cattle tick Boophilus microplus (Canestrini, 1887) (Acari: Ixodidae) (Fernandes et al., 2005b) while that of Magonia pubescens St. Hil, which belongs to the same family as $S$. saponaria is effective against both the mosquito Aedes aegypti (Linnaeus, 1762) (Diptera: Culicidae) (Silva et al., 2004) and R. sanguineus (Fernandes et al., 2005a). These factors influenced the choice of this plant for the present study. Thus, the objective of the study was to evaluate the larvicidal bioactivity of the CEE of the stem peel of $S$. saponaria against $R$. sanguineus.

\section{MATERIAL AND METHODS}

Stem peel and seeds of $S$. saponaria collected in Formosa, Santa Terezinha and other municipalities of Goiás were transported to the laboratory to process CEEs by the method of Silva et al. (2004). Those were then conditioned in amber-tinted glass flasks and transported to the Laboratory of Medical and Veterinary Arthropodology (LAMV) of the Institute of the Tropical Pathology and Public Health (IPTSP) of the Federal University of Goiás (UFG), where they were stored in a desiccator until be ready for use. 
A 5000ppm stock solution was prepared by weighing CEE on an analytical balance with a precision of $0.1 \mathrm{mg}(0.0001 \mathrm{~g})$. The CEE was dissolved in distilled water and left to stand for about $1 \mathrm{~h}$ to facilitate dissolution. It was then homogenized with a magnetic stirrer for about $15 \mathrm{~min}$ and the final volume adjusted with distilled water. Lower concentrations were sequentially obtained by dilution in distilled water and solutions were prepared $24 \mathrm{~h}$ before beginning the bioassays (Fernandes et al., 2005a).

Engorged females of $R$. sanguineus were collected from the walls, roofs and floors of kennels and other microhabitats frequented by naturally infested dogs in several neighborhoods of Goiânia. In the LAMV, they were washed with distilled water and dried on paper towels before being fixed dorsal-side up with doubledsided tape on glass slides in Petri dishes. These were placed in a B.O.D. incubator at $27 \pm 1^{\circ} \mathrm{C}$, $\mathrm{RH} \geq 80 \%$ and $12: 12$ photoperiod for oviposition. Eggs were harvested daily and batches laid on the same day were placed in the same polyethylene tube with screw cap, constituting a pool of eggs (Fernandes, 2000; 2001).

Evaluation of larval sensitivity was based on the larval packet test (lpt) of Fernandes 2005b, incorporating some modifications by Leite (1988); Fernandes (2000; 2001) and FAO (2004), aimed at improving practice and cost without compromising efficiency. Bioassays were performed in a specially constructed biological chamber for testing botanical acaricides at LAMV, acclimatized to $27 \pm 1^{\circ} \mathrm{C}$, $\mathrm{RH}>80 \%$ and a $12: 12 \mathrm{~h}$ natural photophase.

Larvae were exposed to the test solutions in filter paper envelopes $\left(\approx 327 \mathrm{~cm}^{2}\right) \quad$ containing micropores to allow better ventilation. Each envelope was dosed with $2 \mathrm{ml}$ of test solution, uniformly distributed with a pipette on its inner surface. The envelopes of the control group received only distilled water, since no other solvent was necessary to solubilize the extract of this plant. Only larvae aged 14-21 days were used in the tests, from tubes with the highest rates of eclosion (90-100\%), were used in the tests. At least 30 larvae were placed in each envelope, which were sealed by folding over the opening and placing it between two glass slides on a bench. Water-filled glass flasks were placed on top of the slides and also contributed to maintaining adequate humidity in the chamber.

In each bioassay, four replicates of exposures to each concentration tested were carried out, i.e., four envelopes were impregnated with each test concentration. The entire bioassay was repeated on four different days, preparing a new stock solution each day. Mortality was recorded after $48 \mathrm{~h}$ exposure, when the envelopes were opened and inspected under the stereomicroscope. To allow comparison of results with those of other authors, immobile larvae were considered to be dead. Tests which produced over $5 \%$ mortality in the control group were not included in the analyses. The lethal concentrations LC50 (concentration able to kill $50 \%$ of the larvae) and LC99 (able to kill 99\% of the larvae) were calculated by interpolating the mortalities obtained for different concentrations using Probit regression analysis, by the software System for Análises Estatísticas (Sistema...,1995).

\section{RESULTS AND DISCUSSION}

The crude extract of $S$. saponaria showed larvicidal potential against $R$. sanguineus. The $\mathrm{CEE}$ of $S$. saponaria gave an $\mathrm{LC}_{50}$ value of 1994ppm, (confidence interval (CI) of 18912099; $\mathrm{P} \leq 0.05$ ) and $\mathrm{LC}_{99}$ of 3922ppm (CI 34904595, $\mathrm{P} \leq 0.05$ ) (Fig. 1). No significant mortality was observed in the control group. The only published studies on plants for controling of $R$. sanguineus evaluated the CEE of $M$. pubescens (Sapindaceae) (Fernandes et al., 2005a) and the oleoresin of Copaifera reticulata (Leguminosae, Caesalpinioideae) (Fernandes et al., 2004). However, increasing numbers of researchers believe in the potential of plants in the search for acaricides. Encouraging results were also obtained by Fernandes et al. (2004), who tested the oleoresin of $C$. reticulata against larvae of the cattle tick $B$. microplus. 


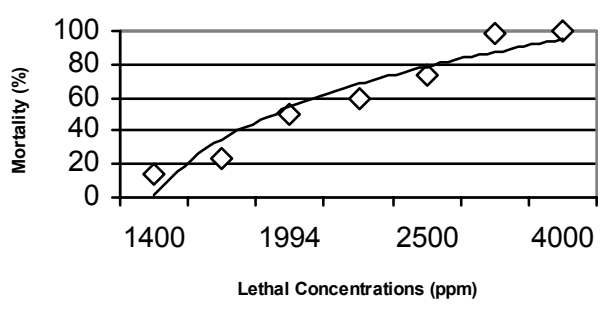

Figure 1. Mortality of Rhiphicephalus sanguineus larvae after $48 \mathrm{~h}$ exposure to different concentrations of the crude ethanolic extract of Sapindus saponaria. The lozenges represent the lethal concentrations and the trend line is derived from logarithmic regression (Probit analysis ).

Prates et al. (1993) also obtained favorable results against $B$. microplus when they evaluated larvicidal activity of chemical components of the essential oil of Melinis minutiflora Beauv, especially alpha-pinene. Chagas et al. (2002) tested three species of Eucalyptus (Myrtaceae) against B. microplus. These authors observed $100 \%$ mortality in larvae submitted to concentrations of $10 \% \quad(\approx 100000 \quad \mathrm{ppm})$ of essential oil of E. staigeriana and E. citriodora, and $20 \%$ of E. globulus. These findings, together with the results of the present study show the potential of $S$. saponaria a botanical acaricide, this plant producing $99 \%$ mortality in larvae of $R$. sanguineus at a low concentration (3922ppm $\approx 0,4 \%$ ), and previously (Fernandes et al., 2005b), in B. microplus larvae at a larger concentration $(6360 \mathrm{ppm} \approx 0,6 \%)$.

Results of the present study show the potential of $S$. saponaria as a botanical acaricide, based on evaluation of CEE of the stem peel. Even more encouraging results could be obtained from seeds, fruits and other parts of this plant, as well as fractions and sub-fractions of the CEE or isolated molecules.

Chungsamarnyart et al. (1991) pointed out that natural acaricides tend to have low toxicities to mammals, induce slow development of resistance and degrade rapidly in the environment. Furthermore, the diverse chemical substances isolated from insecticidal plants are truly novel and unique to these plants (Cascon et al., 2000).

The acaricidal action of $S$. saponaria is probably related to the presence of tannins, similar to those isolated from the CEE of M. pubescens by
Silva et al. (2004). Three (MP-7, MP-8 and MP9) of the nine fractions isolated from this species present activity against larvae of Aedes aegypti. Based on these findings and the results of the present study, future research should involve identification and isolation of bioactive fractions of the $S$. saponaria CEE and evaluation against larvae of $R$. sanguineus. The soapberry should be recognized as an auto-sustainable resource and be to preserved in its natural environment.

\section{ACKNOWLEDGEMENTS}

We thank the financial support received from the CNPq and FUNAPE to carry out this study.

\section{REFERENCES}

ANDEREG, P.I.; PASSOS, L.M.F. Erliquiose canina-revisão. Clin. Vet., v.12, p.31-38, 1999

BURGDORFER, W.; SEXTON, D.J.; GERLOFF, R.K. et al. Rhipicephalus sanguineus: vector of a new spotted fever group rickettsia in the United States. Infect. Immunol., v.12, p.205-210, 1975.

CASCON, V.; GILBERT, B. Characterization of the chemical composition of oleoresins of Copaifera guianensis Desf., Copaifera duckei Dwyer and Copaifera multijuna Hayne. Phytochemistry, v.55, p.773-78, 2000.

COSTA, J.O.; BOTELHO, J.R. Classe Arachnida. In: NEVES, D.P.; MELO, A.L.; GENARO, O. et al. Parasitologia humana, 10.ed. São Paulo: Atheneu, 2003. p.373-391.

CHAGAS, A.C.S.; PASSOS, W.M.; PRATES, H.T. et al. Efeito acaricida de óleos essenciais e concentrados emulsionáveis de Eucalyptus spp. em Boophilus microplus. Braz. J. Vet. Ani. Sci., v.39, p.247-253, 2002.

CHUNGSAMARNYART, N.; JIWAJINDA, S.; RATANAKREETAKUL, C. et al. Practical extraction of sugar apple seeds against tropical cattle ticks. Kasetsart J. (Nat. Sci.), v.25, suppl., p.101-105, 1991.

FAO. Module 1. Ticks: Acaricide resistance; Diagnosis Management and Prevention In: Guidelines Resistance Management and Integrated Parasite Control in Ruminants. Rome: 
FAO Animal Production and Health Division. 2004.

FERNANDES, F.F. In vitro activity of permetrin, cipermetrin and deltamethrin on larvae of Rhipicephalus sanguineus. Arq. Bras. Med. Vet. Zootec., v.52, p.621-626, 2000.

FERNANDES, F.F. Toxicological effects and resistance to pyretroids in Boophilus microplus from Goiás, Brasil. Arq. Bras. Med. Vet. Zootec., v.53, p.548-552, 2001.

FERNANDES, F.F.; BESSA, P.A.D.; SILVA, I.G. et al. Atividade larvicida do extrato bruto etanólico de Magonia pubescens (Sapindaceae) sobre Rhipicephalus sanguineus, o carrapato vermelho do cão (Latreille, 1806) (Acari: Ixodidae). Rev. Anclivepa Brasil, v.3, p.154-156, 2005a.

FERNANDES, F.F.; FREITAS, E.P.S.; COSTA, A.C. et al. larvicidal potential of Sapindus saponaria to control of the cattle tick Boophilus microplus. Pesq. Agropec. Bras., v.40, p.12431245, 2005b.

FERNANDES, F.F.; FREITAS, E.P.S. Analysis of the use of fenthion via epicutaneous in dogs for Rhipicephalus sanguineus control. Rev. Soc. Brasil. Med. Trop., v.34, p.339-342, 2001.

FERNANDES, F.F.; FREITAS, E.P.S.; SILVA, J.R. V. et al. Toxicological effects and in vitro inefficacy of deltamethrin on larvae of Rhipicephalus sanguineus from Goiânia, Goiás, Brazil. Rev. Soc. Brasil. Med. Trop., v.34, p.159165, 2001.

FERNANDES, F.F.; SILVA, I.G.; COSTA, A.C. et al. Larvicidal activity of Copaifera reticulata (Leguminosae., Caesalpinioideae) oil resin to controle of ticks Rhipicephalus sanguineus (Latreille, 1806) and Boophilus microplus (Canestrini, 1887) (Acari, Ixodidae). In: CONGRESSO BRASILEIRO DE ENTOMOLOGIA, 20., 2004, Gramado. Anais... Gramado: SEB, 2004. p. 485. (Resumo).

GUARIN NETO, G.; SANTANA, S.R.; SILVA, J.V. B. Notas etnobotânicas de espécies de Sapindaceae Jusieu. Acta Bot. Bras., v.14, p.327334, 2000.

HERVÉ, J.J. El modo de acción de los pirtroides y el problema de la resistência a estos compuestos. In: NOMINÉ, G. (Ed). Deltmetrín Monografia. Paris: Houssel-Uclaf, 1983, p. 67107.

HOOGSTRAAL, H. Ticks in relation to human diseases caused by Rickettsia species. Ann. Rev. Entomol., v.12, p.377-420, 1967.

LEITE, R.C. Boophilus microplus (CANESTRINI, 1887): Susceptibilidade, uso atual e retrospectivo de carrapaticidas em propriedades das regiões fisiográficas da baixada do Grande Rio e Rio de Janeiro; uma abordagem epidemiológica. 1988. 144f. Tese (Doutorado) - Universidade Federal Rural do Rio de Janeiro, Seropédica, RJ.

MILLER, R.J.; GEORGE, J.E.; GERREIRO, F. et al. Characterization of Acaricide Resistance in Rhipicephalus sanguineus (Latreille) (Acari: Ixodidae) collected from the Corozal Army Veterinary Quarantine Center, Panama. J. Med. Entomol., v.38, p.293-302, 2001.

POTT, A.; POTT, V.J. Plantas do pantanal. Brasília: EMBRAP/CPAP/SPI, 1994. 320p.

PRATES, H.T.; OLIVEIRA, A.B.; LEITE, R.C. et al. Atividade carrapaticida e composição química do óleo essencial de capim-gordura. Pesq. Agropec. Bras., v.5, p.621-625, 1993.

SEXTON, D.J.; BURGDORFER, W.; THOMAS, L. et al. Rocky Mountain spotted fever in Mississippi: survey for spotted fever antibodies in dogs and for spotted fever group Rickettsiae in dogs ticks. Am. J. Epidemiol., v.103, p.192-197, 1976.

SILVA, H.H.G.; SILVA, I.G.; SANTOS, R.M.G. et al. Atividade larvicida de taninos isolados de Magonia pubescens St. Hil.(Sapindaceae) sobre Aedes aegypti (Diptera, Culicidae). Rev. Soc. Brasil. Med. Trop., v.37, p.396-399, 2004.

SISTEMA de análises estatísticas e genéticas SAEG, Viçosa: UFV, 1995.

WANG, R.W.; LIU, Z.Q.; DONG, K. et al. Association of novel mutations in a sodium channel gene with fluvalinate resistance in the mite, Varroa destructor. J. Api. Res., v.41, p.1725, 2002.

WOLDEHIWET, Z.; RISTIC M. Rickettsial and chlamydial diseases of domestic animals. Oxford: Pergamon, 1993. p.427. 